\title{
FDM/FLM/FFF 3D NYOMTATÓK TÍPUSAINAK ÖSSZEHASONLÍTÁSA
}

\author{
Csehi Bálint \\ hallgató, Miskolci Egyetem, Gép- és Terméktervezési Intézet \\ 3515 Miskolc, Miskolc-Egyetemváros, e-mail: cs.balint98@gmail.com \\ Bihari Zoltán \\ egyetemi docens, Miskolci Egyetem, Gép-és Terméktervezési Intézet \\ 3515 Miskolc, Miskolc-Egyetemváros,e-mail: machbz@uni-miskolc.hu
}

\begin{abstract}
Absztrakt
Ez a cikk az FDM/FLM/FFF technológiát használó $3 D$ nyomtatók vázszerkezetét, extruder- és nyomtatófej-kialakitásait vizsgálja. Összehasonlítjuk a különbözö lehetöségeket, azt vizsgálva, hogy milyen hibalehetöségekkel kell számolnunk egy tetszöleges 3D nyomtatónál, annak vázától az egyéb mechanikai elemeivel bezárólag.
\end{abstract}

Kulcsszavak: $3 D$ nyomtató, FDM, FLM, FFF

\begin{abstract}
This article is about the design of framework, extruder and printer head of FDM/FLM/FFF-type $3 D$ printers. We compare the different solutions, examining the possibly occurring errors, depending on the type of the framework and other mechanical parts.
\end{abstract}

Keywords: $3 D$ printer, FDM, FLM, FFF

\section{Bevezetés}

Az FDM, FFF és FLM rövidítések lényegében ugyanazt a gyártástechnológiát jelölik, azonban az FDM a Stratasys cég által birtokolt, jogvédett elnevezés, így a többi gyártó nem használhatja. A mozaikszavak a Fused Deposition Modeling, a Fused Filament Fabrication és a Fused Layer Modeling kifejezések rövidítései, mindhárom kifejezést szálhúzásos rétegmodellezésként vagy rétegnyomtatásként lehet magyarra fordítani.

Az FDM 3D nyomtatók szerkezeti felépítése jelentős változatosságot mutat. A jelenleg kapható gépek jelentős része három tengelyes, Descartes-féle koordináta-rendszert használ. Ritkábban előfordulnak polárkoordináta-rendszerre épülö gépek is, azonban ezek nem túl gyakoriak. Kevés kivételt jelent pár ipari nyomtató, melyek 5 tengelyesek, illetve egy újszerü megoldást jelent a „conveyor belt printer”, ahol a tárgyasztal helyén egy végtelenített, futószalag-szerüen hajtott felületre nyomtatunk, a szalag felületéhez képest 45 fokos síkon mozgó nyomtatófejjel (1. ábra).

Az FDM nyomtatók és a hagyományos háromtengelyes CNC marók jelentős hasonlóságot mutatnak, nem véletlenül. Az első nyomtatókat CNC alapra készítették el, így ugyanazokat a léptetőmotorokat, orsókat, meghajtó áramköröket találjuk a nyomtatókban is. A nyomtatók által feldolgozott fájl kiterjesztése, a gcode kiterjesztés is megegyezik. 


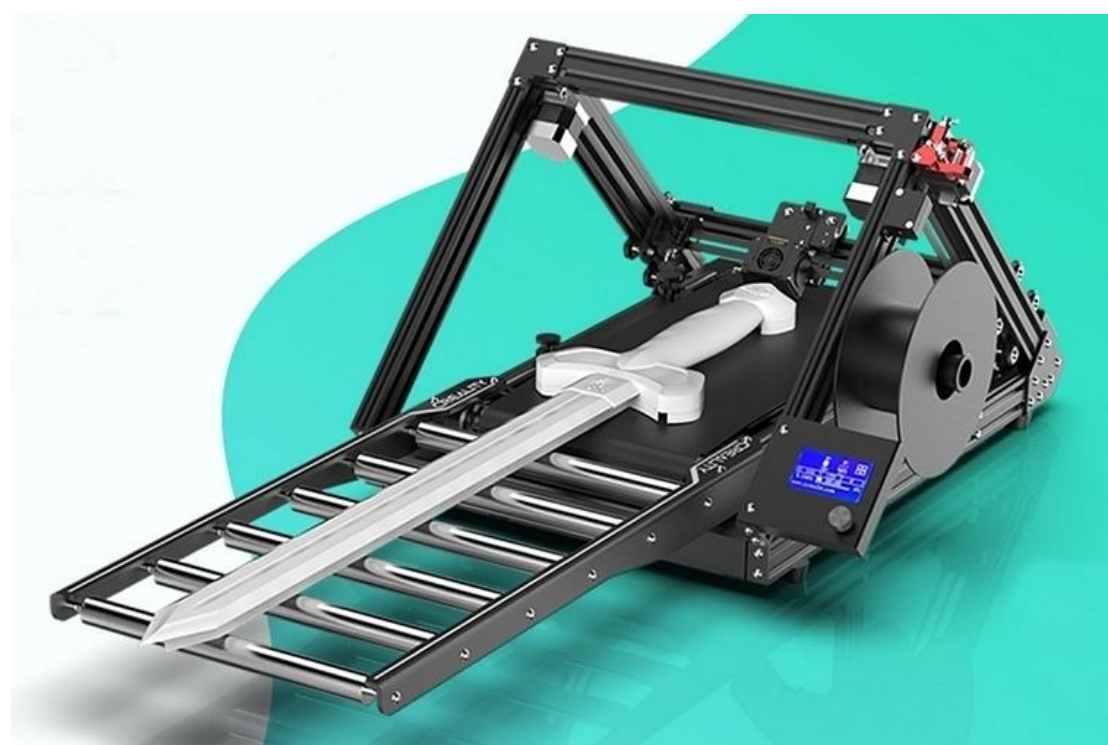

1.ábra. A Creality CR30 nyomtató, a „conveyor belt” típusú 3D nyomtatók egyik elsö képviselöje

Ezeknél a gépeknél megegyezés szerint az $\mathrm{X}$ irány a szélesség, $\mathrm{Y}$ a mélység, és $\mathrm{Z}$ a magasság, így a továbbiakban az X, Y, Z tengely elnevezések ezekre az irányokra utalnak, ahogy a 2. ábra is mutatja.
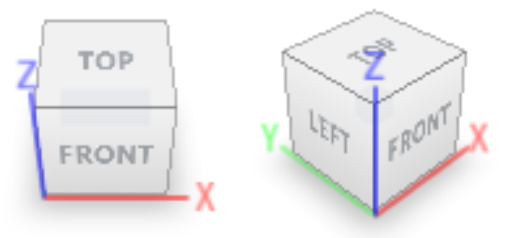

2.ábra. A derékszögü koordinátarendszert használó 3D nyomtatók pozitív tengelyirányai

\section{A Cartesian-típusú nyomtatók}

A leginkább elterjedt szerkezeti felépítés a koordináta-rendszer után egyszerüen cartesiannak nevezett váztípus. Ezen belül három változatot különböztetünk meg, attól függően, hogy a különbözö tengelyeken való elmozdulást hogyan érik el. Az X tengelyen minden esetben a nyomtatófejet mozgatják Kisebb, általában 200·200·200 mm munkatér alatti gépeknél, illetve hobbikategóriás nyomtatóknál gyakori megoldás, hogy a tárgyasztal mozog az Y tengely mentén, függőleges irányban pedig valamilyen orsó segítségével az X tengelyt emelik. Mivel ez a konstrukció a hobbinyomtatók körében általánosnak számít, egy ipari nyomtatót érdemes használni szemléltetésnek, ez pedig a Raise3D E2.,

Ennek a típusú cartesian nyomtatónak a hátránya a tárgyasztal vízszintes irányú mozgatásában rejlik. Ez lényegesen nagyobb mozgó tömeget jelent, ami a nyomtatás időbeli előre haladásával tovább nő. Ez főleg az irányváltáskor fellépő erők szempontjából jelent problémát, hiszen a nagy tömegü mozgó alkatrészek nagyobb tehetetlenséget jelentenek, ez pedig szellemkép-szerü nyomokat hagyhat a nyomtatáson. A nagy mozgó tömeg, illetve a léptetőmotorok és vezérlők korlátozott terhelhetősége miatt a maximális nyomtatási sebesség is limitált, általában $80-100 \mathrm{~mm} / \mathrm{s}$ a maximum, amit a felületi minőség romlása nélkül el lehet érni. 


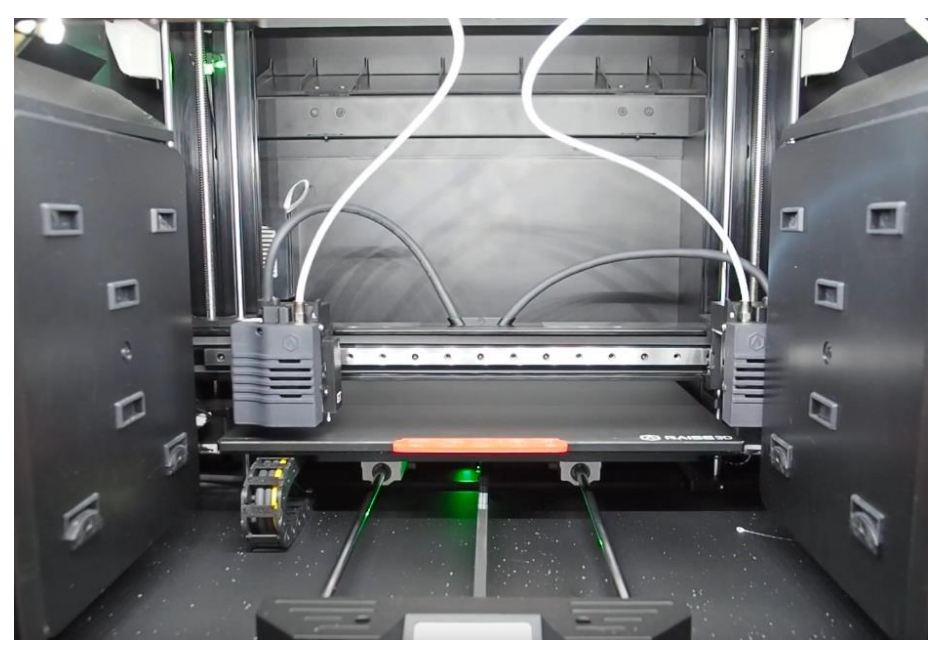

3. ábra. Raise $3 D$ E2 belseje

300·300·300 mm munkatér fölött általában a tárgyasztalt mozgatják a $\mathrm{Z}$ tengely mentén, a nyomtatófej pedig X és Y irányba mozog. Ez kivitelezhető akár egyesített X-Y tengelyekkel, mint a legtöbb ipari nyomtatónél, például a Zortrax M200, M300, vagy a Raise3D Pro2. Ebben a konstrukcióban az X és Y irányú mozgáshoz ugyanakkora erőre van szükség. A másik megoldás, hogy az Y irányú mozgást az $X$ tengely mozgatásával érjük el. Ezt a konstrukciót használja a BQ Witbox, illetve a Craftbot nyomtatóinak többsége.

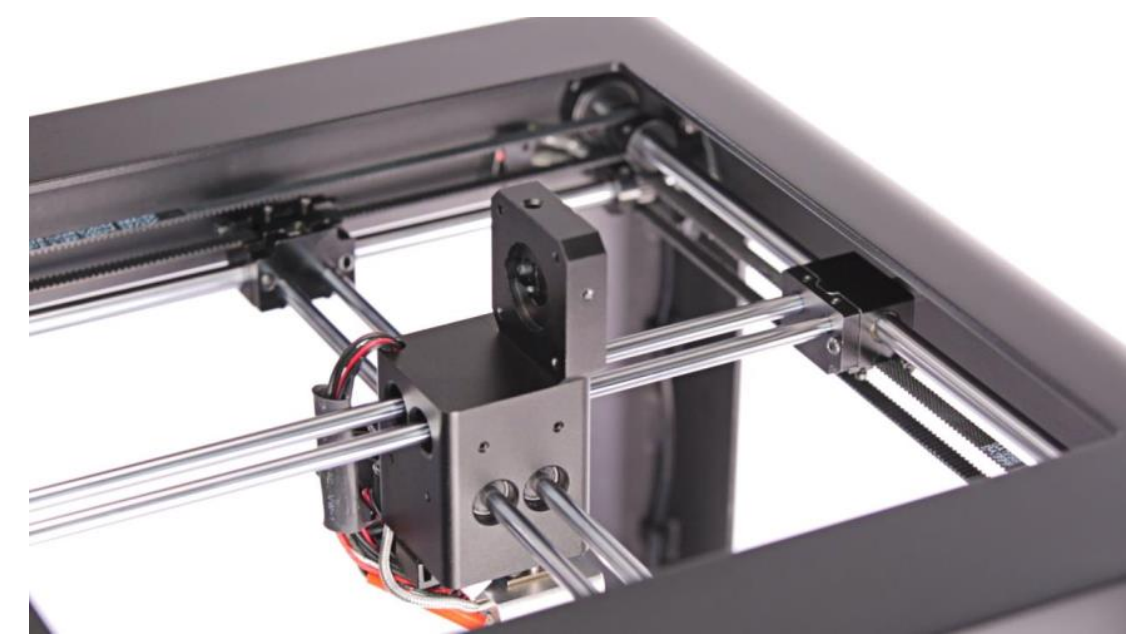

4. ábra. Zortrax M200 X és Y tengelyei. A nyomtatófej direkt extruderes, azonban a képen csak az extruder mechanika látható, a léptetömotor nincs még felszerelve [3]

A harmadik lehetőség, amely föleg a nagy, 400·400·400 mm munkaterü, vagy nagyobb nyomtatókra jellemzö, hogy a tárgyasztal semmilyen irányba nem mozog, és az X-Y tengelyeket tartó keretet mozgatják $Z$ irányba is. Ez a két utóbbi megoldás komolyabb vázat igényel, így hobbinyomtatóknál nem gyakori konstrukció, azonban az ipari használatra szánt nyomtatóknál sokkal több előnnyel jár. 
Általánosságban elmondható mindhárom változatról, hogy kis processzorigényű a vezérlésük, hiszen a gcode fájlból kiolvasott koordinátákat egyszerü műveletekkel át lehet alakítani lépésszámmá, nincs szükség lebegőpontos számításokra. Egyformán a hátrányuk ugyanakkor, hogy nagy méretü, nehéz vázat igényelnek, valamint viszonylag sok a lineáris technika bennük, ez pedig jelentős mértékben növelheti a gépek árát, szemben például a Delta-típusú nyomtatók vázával.

\section{Core-típusú 3D nyomtatók}

Attól függően, hogy melyik tengelyeket vonjuk össze, megkülönböztetünk core-XY, corte-XZ és coreYZ konfigurációkat. Mivel a core-elrendezés egy tengelyen való elmozdulás esetén két motor összehangolt mozgását igényli, a gyakorlatban csak a core-XY konstrukció terjedt el. Ennek oka egyszerü, a $Z$ tengely mozgatására lényegesen kevesebbszer, és kisebb mértékben van szükség, mint az X és Y tengelyek esetében. A coreXY lényege, hogy a klasszikus X és Y tengely helyett A és B jelzésü, a vázhoz fixen rögzített motorokat találunk, a nyomtatófejet kizárólag az 5. ábrán pirossal és kékkel jelölt nyomvonalon vezetett bordásszíjak mozgatják. Így a derékszögủ koordinátarendszerben végzett $\mathrm{X}, \mathrm{Y}$ irányú mozgást az alábbi módon írhatjuk át:

$$
\begin{aligned}
& \Delta \mathrm{A}=\sqrt{2} \cdot(\Delta \mathrm{X}+\Delta \mathrm{Y}) \\
& \Delta \mathrm{B}=\sqrt{2} \cdot(-\Delta \mathrm{X}+\Delta \mathrm{Y})
\end{aligned}
$$

Ezek a műveletek a négyzetgyök miatt lebegőpontos számítást igényelnek, így processzorigényük nagyobb. Ez a konstrukció nem is igazán terjedt el a 3D nyomtatók körében, a kevés kivétel közé tartozik a Makerbot Hypercube Evolution, Two Trees Sapphire Pro és Tronxy X5SA.

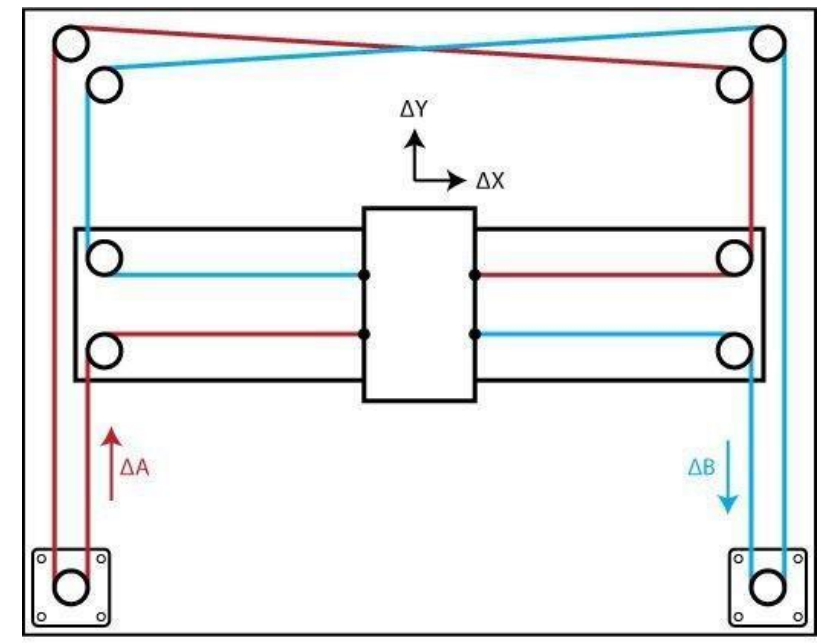

5. ábra. Core-XY típusú $3 D$ nyomtató X és Y tengelyeinek elrendezését szemléltetö sematikus ábra

Az említett típusok azonban mind hobbikategóriás gépek, ipari használatra szánt nyomtatók között nem nagyon terjedt el a típus. Bár előnyének tartják, hogy a motorok nem képezik a mozgatott tömeg részét, illetve megszüntetik a mozgó tengelyre ható csavaró erőket, azonban a hosszú bordásszíjak nagyobb mértékben képesek megnyúlni, így ez a nagyobb processzor-igény mellett egy újabb gyenge pontja a konstrukciónak. 


\section{Delta-típusú 3D nyomtatók}

Az eddigi, kocka vagy téglatest alakú munkaterü gépekkel szemben ez egy merőben eltérő konstrukció. Munkatere egy hengerből és egy kúpból álló testtel jellemezhető, ahogyan a 6. ábrán ez látható. A delta-nyomtatók váza három függőleges tengelyböl áll, a három mozgó kocsi között merev rúddal felfüggesztve találjuk a nyomtatófejet. Az eddigiekkel ellentétben a függőlegesen elmozduló kocsikat nem orsóval, hanem bordásszíj segítségével hajtják.

Előnyük, hogy a munkadarab teljesen mozdulatlan, semmilyen irányú elmozdulást nem végez, így szintén jelentős gyorsulásra és sebességre képesek. A nyomtatófej, mivel gömbcsuklós végü, merev pálcákkal kerül felfüggesztésre, szintén nagyobb gyorsulásra képes, mint az eddig ismertetett típusok.

Hátrányuk, hogy terjedelmes vázat igényelnek, illetve a klasszikus, 8 bites processzorokkal már nem képesek kielégítően együttmüködni, így szintén a komolyabb számítási kapacitásra képes, 32 bites processzorokra van szükség a pontos múködésükhöz.

Ilyen típusú nyomtató például az Anycubic Kossel termékcsalád, mely a 6. ábrán is látható. Jól látható a típus másik hátránya: A nyomtatófej felfüggesztése miatt a gép térfogatának jelentős része kihasználatlan marad.

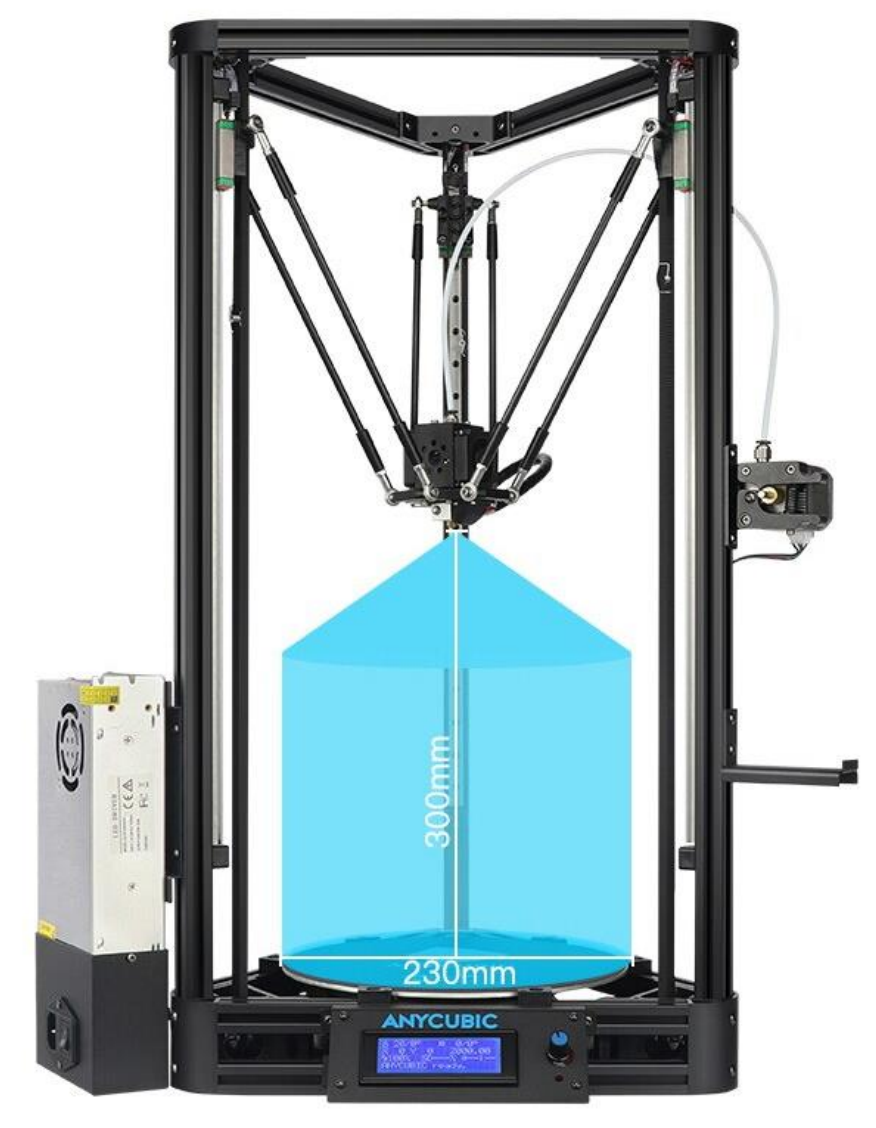

6.ábra. Anycubic Kossel Plus, egy Delta-típusú 3D nyomtató 


\section{5. Összegzés}

A három leggyakoribb típust összehasonlítva, azt állapíthatjuk meg, hogy a legegyszerübb, leginkább előnyös váz a cartesian típusú, annak is az a két változata, ahol a tárgyasztal függőlegesen, vagy semmilyen irányba nem mozog. Itt viszonylag kis méretü a mozgó tömeg, nincsenek feleslegesen hosszú bordásszíjak, illetve nem igényel jelentős processzorteljesítményt a tengelyek vezérlése. További előnye ennek a konstrukciónak, hogy a másik két említett típussal ellentétben lehetôvé teszi a független kettős extruder-nyomtatófej, azaz az IDEX konstrukció használatát. Az IDEX fejjel szerelt nyomtatók képesek egyszerre két munkadarabon is dolgozni, ezzel jelentösen növelve a gép produktivitását. Előnyük még, hogy egyszerü, könnyen burkolhatóak, ami sok, iparban használt alapanyag nyomtatásának elengedhetetlen feltétele.

Az FDM típusú 3D-nyomtatók váza azonban olyan nagy változatosságot mutat, hogy egy ilyen rövid írásban nincs lehetőség alaposan bemutatni az összes variációt, és azok minden előnyét és hátrányát.

\section{Köszönetnyilvánítás}

A cikkben ismertetett kutató munka az EFOP-3.6.1-16-2016-00011 jelü „Fiatalodó és Megújuló Egyetem - Innovatív Tudásváros - a Miskolci Egyetem intelligens szakosodást szolgáló intézményi fejlesztése" projekt részeként - a Széchenyi 2020 keretében - az Európai Unió támogatásával, az Európai Szociális Alap társfinanszírozásával valósul meg.

\section{Irodalom}

[1] Finnes, T.: High definition 3D printing - Comparing SLA and FDM printing technologies, The Journal of Undergraduate Research: Vol. 13, Article 3., (2015) South Dakota, USA

[2] Karbantartási útmutató Zortrax M200/M200 Plus típusú 3D nyomtatókhoz, 2019.

[3] Torta, S., Torta, J.: 3D Printing - An introduction, Mercury Learning and Information Kiadó, Boston, USA, 2019. 